\title{
Herbidospora osyris sp. nov., isolated from surface- sterilized tissue of Osyris wightiana Wall. ex Wight
}

Correspondence

Wen-Jun Li

wjli@ynu.edu.cn or

liact@hotmail.com

\author{
Jie Li, ${ }^{1}$ Guo-Zhen Zhao, ${ }^{1}$ Sheng Oin, ${ }^{1}$ Wen-Yong Zhu, ${ }^{1}$ Li-Hua Xu ${ }^{1}$ \\ and Wen-Jun $\mathrm{Li}^{1,2}$
}
${ }^{1}$ The Key Laboratory for Microbial Resources of the Ministry of Education, PR China, and Laboratory for Conservation and Utilization of Bio-Resources, Yunnan Institute of Microbiology, Yunnan University, Kunming 650091, PR China
${ }^{2}$ Guangdong Key Laboratory of Marine Materia Medica, South China Sea Institute of Oceanology, Chinese Academy of Sciences, Guangzhou 510301, PR China

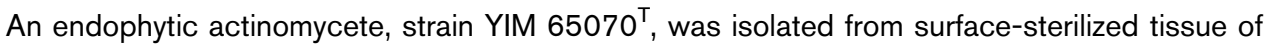
Osyris wightiana Wall. ex Wight collected from Yunnan province, south-west China, and characterized by using a polyphasic approach. Strain YIM $65070^{\top}$ had morphological and chemotaxonomic markers that were consistent with its classification in the genus Herbidospora. Phylogenetic analysis based on almost complete 16S rRNA gene sequences indicated that strain YIM $65070^{\top}$ was phylogenetically very closely related to Herbidospora cretacea IFO $15474^{\top}$. DNA-DNA hybridization experiments confirmed the separate genomic status of strains YIM $65070^{\top}$ and $H$. cretacea DSM 44071 ${ }^{\top}$. Moreover, strain YIM $65070^{\top}$ could be distinguished from $H$. cretacea DSM $44071^{\top}$ by differences in several phenotypic characteristics such as tolerance to $\mathrm{NaCl}$, degradation activity, utilization of sole carbon and nitrogen sources and the cellular fatty acid contents. On the basis of phenotypic and phylogenetic evidence, strain $\mathrm{YIM} 65070^{\top}$ was identified as a novel species of the genus Herbidospora, for which the name Herbidospora osyris sp. nov. is proposed, with YIM $65070^{\top}$ (=CCTCC AA $208019^{\top}=$ DSM $45214^{\top}$ ) as the type strain.
\end{abstract}

The genus Herbidospora of the family Streptosporangiaceae was first described by Kudo et al. (1993). At the time of writing, the genus comprises only one recognized species, Herbidospora cretacea (Kudo et al., 1993). The members of this genus produce branching substrate mycelia, but no distinct aerial hyphae. Short chains of non-motile spores (10-30 spores per chain) are borne on the tips of sporophores, which are derived from the vegetative mycelia in clusters. Cell walls contain meso-diaminopimelic acid and $N$-acetylated muramic acid, but lack a significant amount of glycine. Whole-cell hydrolysates contain a trace amount of madurose. The phospholipid pattern is the type PIV pattern of Lechevalier et al. (1977). The cellular fatty acid composition is characterized by the presence of isohexadecanoic, $n$-hexadecanoic, $n$-heptadecenoic, 10methyl heptadecanoic and 2-hydroxy acids. The predominant menaquinone for the genus is $\mathrm{MK}-10\left(\mathrm{H}_{4}\right)$ and $\mathrm{MK}$ $10\left(\mathrm{H}_{6}\right), \mathrm{MK}-10\left(\mathrm{H}_{2}\right), \mathrm{MK}-10\left(\mathrm{H}_{0}\right)$ and MK-9 $\left(\mathrm{H}_{4}\right)$ are also present as minor components. The $\mathrm{G}+\mathrm{C}$ contents of the genomic DNA are 69-71 mol\%.

The GenBank/EMBL/DDBJ accession number for the $16 \mathrm{~S}$ rRNA gene sequence of strain YIM $65070^{\top}$ is FJ214356.
Strain YIM $65070^{\mathrm{T}}$ was isolated as part of a discovery and identification programme for endophytic actinomycetes from plants in Yunnan province, south-west China. Strain YIM $65070^{\mathrm{T}}$ was isolated from surface-sterilized tissue of Osyris wightiana Wall. ex Wight. The surface sterilization and isolation procedures were performed according to previously described methods (Li et al., 2009). The purified strain was routinely cultured on YIM 38 medium [4 g malt extract, $4 \mathrm{~g}$ yeast extract, $4 \mathrm{~g}$ glucose, vitamin mixture $(0.25 \mathrm{mg}$ biotin and $0.5 \mathrm{mg}$ each of $p$-aminobenzoic acid, calcium pantothenate, inositol, niacin, pyridoxine- $\mathrm{HCl}$, riboflavin and thiamine- $\mathrm{HCl}$ ), $20 \mathrm{~g}$ agar; $\mathrm{pH}$ 7.2] at $28^{\circ} \mathrm{C}$ and stored as a glycerol suspension $(20 \%, \mathrm{v} / \mathrm{v})$ at $-70{ }^{\circ} \mathrm{C}$.

Genomic DNA extraction, amplification and 16S rRNA gene sequencing were performed as described previously by Li et al. (2007). An almost complete $16 \mathrm{~S}$ rRNA gene sequence of strain YIM $65070^{\mathrm{T}}$, comprising $1425 \mathrm{bp}$, was obtained and aligned with corresponding sequences of $H$. cretacea and other members of the family Streptosporangiaceae (retrieved from the GenBank/EMBL/DDBJ database) using CLUSTAL_x (Thompson et al., 1997). The resulting alignment was corrected manually and a phylogenetic tree was constructed using the neighbour-joining (Saitou \& Nei, 1987) tree-making algorithm from MEGA 
version 4.0 (Tamura et al., 2007). The topologies of the resultant trees were evaluated by using bootstrap analysis (Felsenstein, 1985) based on 1000 resampled datasets.

The phylogenetic positions of the organisms revealed that strain YIM $65070^{\mathrm{T}}$ formed a separate clade with $\mathrm{H}$. cretacea (Fig. 1). A high sequence similarity value of $99.9 \%$ was found between strains YIM $65070^{\mathrm{T}}$ and $H$. cretacea IFO $15474^{\mathrm{T}}$. In order to investigate the genomic relatedness between these two strains, DNA-DNA hybridization was performed according to the method described by He et al. (2005). The experiment was performed with three replications. The level of DNA-DNA relatedness $(62.9 \%$ mean value, SD $3.4 \%$ ) supported the findings that these two strains belong to different genomic species.

Cultural characteristics were determined after 3 weeks incubation at $28{ }^{\circ} \mathrm{C}$, according to the methods of the International Streptomyces Project (ISP; Shirling \& Gottlieb, 1966). Czapek's agar and nutrient agar were prepared as described by Dong \& Cai (2001). Colour determination was performed by using colour chips from the ISCC-NBS colour charts (standard samples, no. 2106) (Kelly, 1964). After incubation on YIM 38 medium at $28{ }^{\circ} \mathrm{C}$ for 27 days, morphological properties were examined using a light microscope (BH-2; Olympus) and a scanning electron microscope (Philips XL30; ESEM-TMP).

Growth at various temperatures, $\mathrm{pH}$ values and $\mathrm{NaCl}$ concentrations was examined according to $\mathrm{Xu}$ et al. (2005) using YIM 38 medium as the basal medium. Carbon source utilization was determined according to the methods of Shirling \& Gottlieb (1966) and Gordon et al. (1974). Oxidase activity was determined from the oxidation of tetramethyl- $p$-phenylenediamine. Catalase activity was determined with $3 \% \mathrm{H}_{2} \mathrm{O}_{2}$ according to standard methods. Other physiological and biochemical features were tested using standard procedures (Goodfellow, 1971; Williams et al., 1983).
Freeze-dried cells for chemotaxonomic analysis were obtained from cultures grown in tryptic soy broth (TSB) for 5 days at $28{ }^{\circ} \mathrm{C}$. The analysis of the cellular fatty acid composition was accomplished by following the instructions of the Microbial Identification System (MIDI) (Sasser, 1990). The amino acids and sugars of the wholecell hydrolysates were determined using TLC as described by Staneck \& Roberts (1974). Phospholipids were identified according to published procedures (Minnikin et al., 1979; Collins \& Jones, 1980). Menaquinones were extracted (Collins et al., 1977) and separated by HPLC (Tamaoka et al., 1983). The G $+\mathrm{C}$ content of the genomic DNA was determined by the HPLC method according to Mesbah et al. (1989).

Strain YIM $65070^{\mathrm{T}}$ produced branched and unfragmented substrate mycelia; no distinct aerial hyphae were found with light or scanning electron microscopy. Straight, short chains of non-motile spores (10-25 spores per chain) were borne on the tips of sporophores, which were derived from the vegetative mycelia in clusters. Spores were oval and the spore surface was smooth (Fig. 2). The cultural characteristics of isolate YIM $65070^{\mathrm{T}}$ are shown in Table 1 . The vegetative mycelia were yellow-white to yellowish brown, no soluble pigments were produced on any of the media tested. Sporulation was poor and when sporulation occurred, the surface of the colony was white. These morphological properties were consistent with those of the genus Herbidospora. Physiological and biochemical test results are given in detail in Table 2 and in the species description.

Strain YIM $65070^{\mathrm{T}}$ contained meso-diaminopimelic acid as the diagnostic diamino acid of the cell-wall peptidoglycan. The whole-cell hydrolysates contained ribose, glucose, galactose, madurose and trace amounts of mannose. The quinone profile was composed of the compounds $\mathrm{MK}$ $10\left(\mathrm{H}_{4}\right)$, MK-10 $\left(\mathrm{H}_{2}\right)$, MK-10 $\left(\mathrm{H}_{0}\right)$, MK-9 $\left(\mathrm{H}_{4}\right)$, MK-10 $\left(\mathrm{H}_{6}\right)$, MK-9 $\left(\mathrm{H}_{2}\right)$ and MK-9 $\left(\mathrm{H}_{0}\right)$ in the ratio $53: 29: 5: 5: 4: 2: 2$.

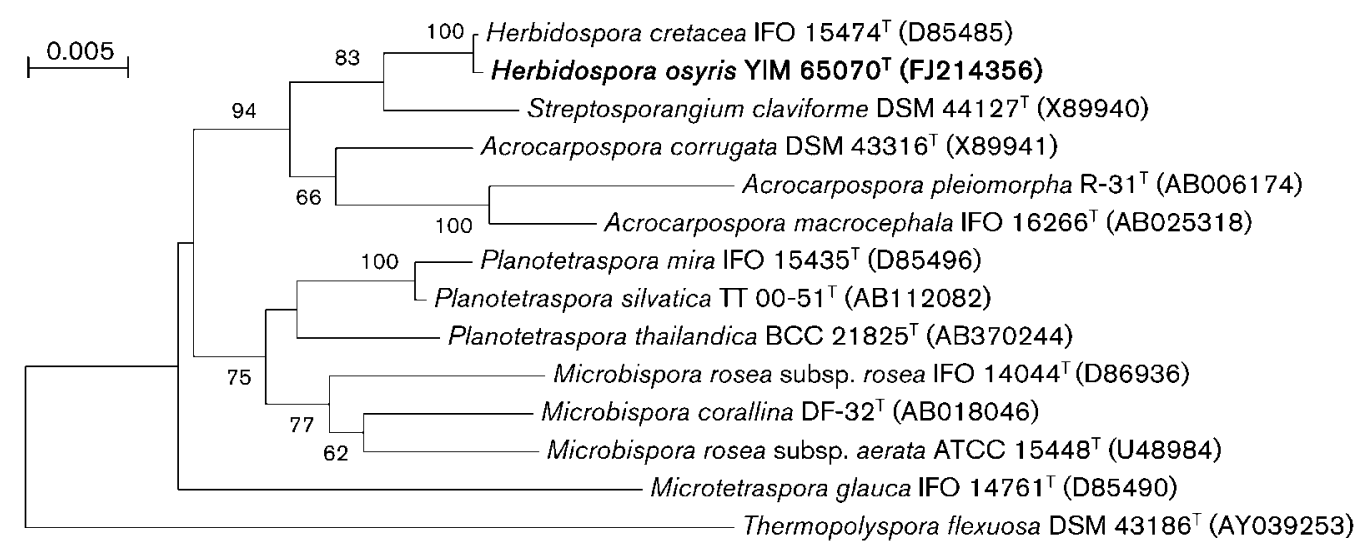

Fig. 1. Neighbour-joining tree based on 16S rRNA gene sequences showing the phylogenetic relationships between strain YIM $65070^{\top}$ and representative species of the family Streptosporangiaceae. Bootstrap values (expressed as percentages of 1000 replications) $>50 \%$ are given at the nodes. Bar, $1 \mathrm{nt}$ substitution per $200 \mathrm{nt}$. 


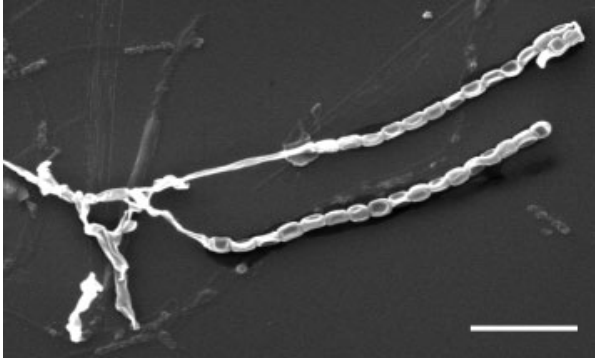

Fig. 2. Scanning electron micrograph of cells of strain YIM $65070^{\top}$ after growth on YIM 38 medium at $28^{\circ} \mathrm{C}$ for 27 days. Bar, $5 \mu \mathrm{m}$.

Phosphatidylethanolamine, phosphatidylinositol and two unknown phosphoglycolipids were the major phospholipids, with moderate amounts of glucosamine-containing phospholipid, diphosphatidylglycerol and two phosphatidylinositol mannosides. The fatty acid contents of strains YIM $65070^{\mathrm{T}}$ and H. cretacea DSM $44071^{\mathrm{T}}$ are shown in Table 3. The G $+\mathrm{C}$ content of the genomic DNA of strain YIM $65070^{\mathrm{T}}$ was $70.4 \mathrm{~mol} \%$.

In the phylogenetic analysis, strain YIM $65070^{\mathrm{T}}$ was found to be closely related to Streptosporangium claviforme DSM $44127^{\mathrm{T}}$, Acrocarpospora corrugata DSM $43316^{\mathrm{T}}$, Acrocarpospora macrocephala IFO $16266^{\mathrm{T}}$, Acrocarpospora pleiomorpha $\mathrm{R}-31^{\mathrm{T}}$, Planotetraspora silvatica TT $00-51^{\mathrm{T}}$, Planotetraspora mira IFO $15435^{\mathrm{T}}$ and Planotetraspora thailandica BCC $21825^{\mathrm{T}}$. The $16 \mathrm{~S}$ rRNA gene sequence similarities between these species were $98.9 \%, 97.9 \%$, $97.0 \%, 96.9 \%, 97.8 \%, 97.6 \%$ and $97.5 \%$, respectively. According to the results obtained by Petrolini et al. (1992), the morphological features of S. claviforme DSM $44127^{\mathrm{T}}$ were similar to those of strains YIM $65070^{\mathrm{T}}$ and H. cretacea DSM $44071^{\mathrm{T}}$. When the results of phylogenetic analysis were analysed, it was found that the taxonomic position of S. claviforme DSM $44127^{\mathrm{T}}$ remained ambiguous and it is suggested that further characteristics should be determined. Isolate YIM $65070^{\mathrm{T}}$ and H. cretacea DSM $44071^{\mathrm{T}}$ could be distinguished from the genera Acrocarpospora and
Planotetraspora by means of their morphological properties and predominant menaquinones. Both strains YIM $65070^{\mathrm{T}}$ and $H$. cretacea DSM $44071^{\mathrm{T}}$ produce non-fragmented branched substrate mycelia, but true aerial hyphae are not formed. Short chains of non-motile spores (10-30 spores per chain) are borne on the tips of sporophores, which are derived from the vegetative mycelia in clusters. Members of genus Acrocarpospora produce spherical and club-shaped structures on the tips of the aerial mycelium, these structures contain coiled spore chains and the spores are non-motile (Tamura et al., 2000). Members of genus Planotetraspora produce long, cylindrical sporangia at the ends of short sporangiophores in aerial hyphae, with each sporangium containing four spores in a single row and the spores may exhibit motility (Tamura \& Sakane, 2004). In addition to the morphological differences, strains YIM $65070^{\mathrm{T}}$ and $\mathrm{H}$. cretacea DSM $44071^{\mathrm{T}}$ have MK-10 $\left(\mathrm{H}_{4}\right)$ as the predominant menaquinone, however, $\mathrm{MK}-9\left(\mathrm{H}_{4}\right)$ is the major component among members of the genera Acrocarpospora and Planotetraspora. Both morphological and chemotaxonomic properties indicated that strains YIM $65070^{\mathrm{T}}$ and H. cretacea DSM $44071^{\mathrm{T}}$ were distinct from their phylogenetic neighbours.

According to the results of simultaneous experiments, many phenotypic differences between strains YIM $65070^{\mathrm{T}}$ and $H$. cretacea DSM $44071^{\mathrm{T}}$ were observed, including differences in tolerance to $\mathrm{NaCl}$, hydrolysis of Tween 80 , utilization of sole carbon and nitrogen sources and the fatty acid contents (Tables 2 and 3). Strain YIM $65070^{\mathrm{T}}$ tolerated $\mathrm{NaCl}$ concentrations of $3 \%(\mathrm{w} / \mathrm{v})$ and did not hydrolyse Tween 80 . It utilized amygdalin, arbutin, glycerol, inositol, melibiose, raffinose, salicin, sodium DLmalate, D-tagatose, trehalose and turanose as sole carbon sources, but none of these sources were used by $H$. cretacea DSM $44071^{\mathrm{T}}$. Strain YIM $65070^{\mathrm{T}}$ utilized adenine, Lcysteine and xanthine, none of which were used by $H$. cretacea DSM $44071^{\mathrm{T}}$. In contrast, $H$. cretacea DSM $44071^{\mathrm{T}}$ utilized L-arginine, L-asparagine, DL-methionine and Lvaline. The cellular fatty acid profile of strain YIM $65070^{\mathrm{T}}$ did not contain any 2-hydroxy acids, but minor to trace amounts of $\mathrm{C}_{16: 0}$ iso $2-\mathrm{OH}, \mathrm{C}_{17: 0} 2-\mathrm{OH}, \mathrm{C}_{15: 0} 2-\mathrm{OH}$, $\mathrm{C}_{16: 0} 2-\mathrm{OH}$ and $\mathrm{C}_{17: 0}$ iso 2-OH were detected in $H$.

Table 1. Cultural characteristics of strain YIM $65070^{\top}$

No diffusible pigments were produced on any of the media.

\begin{tabular}{|lcccc|}
\hline Media & Growth & Reverse side colour & Sporulation & Aerial mass colour \\
\hline Czapek's agar & Good & Yellow-white & Poor & White \\
Glycerol-asparagine agar (ISP 5) & Poor & Pale orange-yellow & None & White \\
Inorganic salts-starch agar (ISP 4) & Moderate & Yellowish brown & Poor & None \\
Nutrient agar & Poor & Grey-yellow & None & - \\
Oatmeal agar (ISP 3) & Poor & Yellow-white & None & - \\
Potato dextrose agar (PDA) & Poor & Grey-yellow & Moderate & White \\
Yeast extract-malt extract agar (ISP 2) & Good & Grey-yellow & Moderate & White \\
YIM 38 agar & Good & Grey-yellow & & \\
\hline
\end{tabular}


Table 2. Physiological characteristics that differentiate strain YIM $65070^{\top}$ from its closest phylogenetic neighbour H. cretacea DSM $44071^{\top}$

Strains: 1 , YIM $65070^{\mathrm{T}} ; 2$, DSM $44071^{\mathrm{T}} .+$, Positive; -, negative; $\mathrm{W}$, weakly positive.

\begin{tabular}{|lcc|}
\hline Characteristic & $\mathbf{1}$ & $\mathbf{2}$ \\
\hline Tween 80 hydrolysis & - & + \\
Growth in $3 \% \mathrm{NaCl}$ & + & - \\
Utilization as sole carbon sources: & & \\
Amygdalin & + & - \\
Arbutin & + & - \\
Glycerol & + & - \\
Inositol & + & - \\
Melibiose & + & - \\
Raffinose & + & - \\
Salicin & + & - \\
Sodium DL-malate & + & - \\
D-Tagatose & + & - \\
Trehalose & + & - \\
Turanose & + & - \\
Utilization as sole nitrogen sources: & & \\
Adenine & + & - \\
L-Arginine & - & + \\
L-Asparagine & - & + \\
L-Cysteine & + & - \\
DL-Methionine & - & W \\
L-Valine & - & + \\
Xanthine & + & - \\
& & \\
\hline
\end{tabular}

cretacea DSM $44071^{\mathrm{T}}$. Although the major components of fatty acids of these two strains were qualitatively similar, the contents were significantly different.

On the basis of the results obtained in this study, the level of DNA-DNA relatedness $(<70 \%)$ and many phenotypic characteristics supported the conclusion that strains YIM $65070^{\mathrm{T}}$ and $H$. cretacea DSM $44071^{\mathrm{T}}$ belong to separate species. Therefore, it is suggested that strain YIM $65070^{\mathrm{T}}$ represents a novel species of the genus Herbidospora, for which the name Herbidospora osyris sp. nov. is proposed.

\section{Description of Herbidospora osyris sp. nov.}

Herbidospora osyris (o.sy'ris. N.L. gen. n. of Osyris, the plant genus from which this species was isolated).

Forms yellow-white to yellowish brown substrate mycelia on the media tested. When sporulation occurs, the surface of the colony is white. No soluble pigments are produced on nutrient, Czapek's, ISP 2, ISP 3, ISP 4, ISP 5, PDA or YIM 38 agars. Short chains of spores (10-25 spores per chain) are borne at the tips of sporophores, which are derived from the vegetative mycelia in clusters. Growth occurs at $10-37{ }^{\circ} \mathrm{C}$ and $\mathrm{pH} 6.0-8.0 . \mathrm{NaCl}$ is tolerated at up to $3 \%(\mathrm{w} / \mathrm{v})$. Catalase is produced. Negative for the VogesProskauer and methyl red tests, for the oxidase reaction, for production of $\mathrm{H}_{2} \mathrm{~S}$, for nitrate reduction and for milk
Table 3. Fatty acid profiles (\%) of strains $\mathrm{YIM} 65070^{\top}$ and H. cretacea DSM $44071^{\top}$

Strains: 1 , YIM $65070^{\mathrm{T}} ; 2$, DSM $44071^{\mathrm{T}}$.

\begin{tabular}{|c|c|c|}
\hline Fatty acid & 1 & 2 \\
\hline $\mathrm{C}_{13: 0}$ & 3.19 & 1.52 \\
\hline $\mathrm{C}_{14: 0}$ iso & 5.89 & 1.63 \\
\hline $\mathrm{C}_{14: 0}$ & 0.99 & 0.56 \\
\hline $\mathrm{C}_{15: 0}$ iso & 2.32 & 1.12 \\
\hline $\mathrm{C}_{15: 0}$ anteiso & & 0.24 \\
\hline $\mathrm{C}_{15: 0}$ & 11.53 & 8.48 \\
\hline $\mathrm{C}_{16: 0}$ iso & 21.82 & 11.85 \\
\hline $\mathrm{C}_{16: 1}$ cis 9 & & 0.93 \\
\hline $\mathrm{C}_{16: 0}$ & 1.70 & 2.79 \\
\hline $\mathrm{C}_{15: 0} 2-\mathrm{OH}$ & & 0.96 \\
\hline$C_{16: 0}$ 10-methyl & & 0.63 \\
\hline $\mathrm{C}_{17: 0}$ iso & 1.27 & 1.10 \\
\hline $\mathrm{C}_{17: 0}$ anteiso & & 0.68 \\
\hline $\mathrm{C}_{17: 1}$ cis 9 & 9.34 & 16.76 \\
\hline $\mathrm{C}_{16: 0}$ iso $2-\mathrm{OH}$ & & 2.74 \\
\hline $\mathrm{C}_{17: 0}$ & 9.10 & 15.65 \\
\hline $\mathrm{C}_{16: 0} 2-\mathrm{OH}$ & & 0.50 \\
\hline $\mathrm{C}_{17: 0}$ 10-methyl & 31.73 & 24.53 \\
\hline $\mathrm{C}_{18: 3}$ cis $6,12,14$ & & 0.39 \\
\hline $\mathrm{C}_{18: 0}$ iso & & 0.79 \\
\hline $\mathrm{C}_{18: 1}$ cis 9 & & 0.80 \\
\hline $\mathrm{C}_{17: 0}$ iso $2-\mathrm{OH}$ & & 0.40 \\
\hline $\mathrm{C}_{18: 0}$ & 1.12 & 1.59 \\
\hline $\mathrm{C}_{17: 0} 2-\mathrm{OH}$ & & 1.88 \\
\hline TBSA C $_{18: 0} 10$-methyl & & 0.64 \\
\hline $\mathrm{C}_{19: 0}$ & & 0.38 \\
\hline $\mathrm{C}_{17: 1}$ iso $\mathrm{I} /$ antei $\mathrm{B}$ & & 0.46 \\
\hline
\end{tabular}

coagulation and peptonization. Tweens 20 and 40 and urea are hydrolysed, but Tween 80 , gelatin, starch and cellulose are not hydrolysed. Utilizes amygdalin, arbutin, cellobiose, aesculin, D-fructose, D-galactose, glycerol, inositol, maltose, D-mannitol, D-mannose, melibiose, raffinose, D-ribose, salicin, sodium DL-malate, D-tagatose, trehalose, turanose and D-xylose as sole carbon sources. D-Adonitol, Darabinose, dulcitol, erythritol, D-lactose, L-rhamnose, Dsorbitol, L-sorbose and xylitol are not utilized. Adenine, L-alanine, L-cysteine, L-cystine, L-histidine, L-lysine, Lphenylalanine, L-proline, L-serine, L-threonine, L-tyrosine and xanthine can be used as sole nitrogen sources, but not L-arginine, L-asparagine, L-glutamic acid, glycine, hypoxanthine, DL-methionine or L-valine. The diagnostic amino acid is meso-diaminopimelic acid and ribose, glucose, galactose, madurose and trace amounts of mannose are present in the whole-cell hydrolysates. The predominant menaquinone is $\mathrm{MK}-10\left(\mathrm{H}_{4}\right)$. MK- $10\left(\mathrm{H}_{2}\right), \mathrm{MK}-10\left(\mathrm{H}_{0}\right)$, MK-9 $\left(\mathrm{H}_{4}\right)$, MK-10 $\left(\mathrm{H}_{6}\right)$, MK-9 $\left(\mathrm{H}_{2}\right)$ and MK-9 $\left(\mathrm{H}_{0}\right)$ are also present as moderate to minor components. Phospholipids are phosphatidylethanolamine, phosphatidylinositol, two unknown phosphoglycolipids, glucosamine-containing phospholipid, diphosphatidylglycerol and two phosphatidylinositol mannosides. Fatty acids are 
$\mathrm{C}_{17: 0}$ 10-methyl, $\mathrm{C}_{16: 0}$ iso, $\mathrm{C}_{15: 0}, \mathrm{C}_{17: 1}$ cis $9, \mathrm{C}_{17: 0}, \mathrm{C}_{14: 0}$ iso, $\mathrm{C}_{13: 0}, \mathrm{C}_{15: 0}$ iso, $\mathrm{C}_{16: 0}, \mathrm{C}_{17: 0}$ iso, $\mathrm{C}_{18: 0}$ and $\mathrm{C}_{14: 0}$.

The type strain, YIM $65070^{\mathrm{T}}\left(=\right.$ CCTCC AA $208019^{\mathrm{T}}=$ DSM $45214^{\mathrm{T}}$ ), was isolated from a surface sterilized plant sample, Osyris wightiana Wall. ex Wight, collected from Yunnan province, south-west China. The $\mathrm{G}+\mathrm{C}$ content of the genomic DNA of the type strain is $70.4 \mathrm{~mol} \%$.

\section{Acknowledgements}

We are grateful to Professor Hans-Peter Klenk for providing the type strain of Herbidospora cretacea DSM $44071^{\mathrm{T}}$. This research was supported by the National Basic Research Program of China (No. 2010CB83380) and Yunnan Provincial Natural Science Foundation (No. 2009DA002).

\section{References}

Collins, M. D. \& Jones, D. (1980). Lipids in the classification and identification of coryneform bacteria containing peptidoglycans based on 2,4-diaminobutyric acid. J Appl Bacteriol 48, 459-470.

Collins, M. D., Pirouz, T., Goodfellow, M. \& Minnikin, D. E. (1977). Distribution of menaquinones in actinomycetes and corynebacteria. J Gen Microbiol 100, 221-230.

Dong, X.-Z. \& Cai, M.-Y. (editors) (2001). Determination of biochemical properties. In Manual for the Systematic Identification of General Bacteria, pp. 370-398. Beijing: Science Press (in Chinese).

Felsenstein, J. (1985). Confidence limits on phylogenies: an approach using the bootstrap. Evolution 39, 783-791.

Goodfellow, M. (1971). Numerical taxonomy of some nocardioform bacteria. J Gen Microbiol 69, 33-80.

Gordon, R. E., Barnett, D. A., Handerhan, J. E. \& Pang, C. H.-N. (1974). Nocardia coeliaca, Nocardia autotrophica, and the nocardin strain. Int J Syst Bacteriol 24, 54-63.

He, L., Li, W., Huang, Y., Wang, L. M., Liu, Z. H., Lanoot, B. J., Vancanneyt, M. \& Swings, J. (2005). Streptomyces jietaisiensis sp. nov. isolated from soil in northern China. Int J Syst Evol Microbiol 55, 1939-1944.

Kelly, K. L. (1964). Inter-Society Color Council - National Bureau of Standards Color-Name Charts Illustrated with Centroid Colors. Washington, DC: US Government Printing Office.

Kudo, T., Itoh, T., Miyadoh, S., Shomura, T. \& Seino, A. (1993). Herbidospora gen. nov., a new genus of the family Streptosporangiaceae Goodfellow et al. 1990. Int J Syst Bacteriol 43, 319-328.

Lechevalier, M. P., De Bièvre, C. \& Lechevalier, H. A. (1977). Chemotaxonomy of aerobic actinomycetes: phospholipid composition. Biochem Syst Ecol 5, 249-260.

Li, W. J., Xu, P., Schumann, P., Zhang, Y. Q., Pukall, R., Xu, L. H., Stackebrandt, E. \& Jiang, C. L. (2007). Georgenia ruanii sp. nov., a novel actinobacterium isolated from forest soil in Yunnan (China) and emended description of the genus Georgenia. Int J Syst Evol Microbiol 57, 1424-1428.

Li, J., Zhao, G. Z., Qin, S., Zhu, W. Y., Xu, L. H. \& Li, W. J. (2009). Streptomyces sedi sp. nov., isolated from a surface-sterilized tissue of Sedum sp. Int J Syst Evol Microbiol 59, 1492-1496.

Mesbah, M., Premachandran, U. \& Whitman, W. B. (1989). Precise measurement of the $\mathrm{G}+\mathrm{C}$ content of deoxyribonucleic acid by high-performance liquid chromatography. Int J Syst Bacteriol 39, 159167.

Minnikin, D. E., Collins, M. D. \& Goodfellow, M. (1979). Fatty acid and polar lipid composition in the classification of Cellulomonas, Oerskovia and related taxa. J Appl Bacteriol 47, 87-95.

Petrolini, B., Quaroni, S., Sardi, P., Saracchi, M. \& Andriollo, N. (1992). A sporangiate actinomycete with unusual morphological features: Streptosporangium claviforme sp. nov. Actinomycetes 3, 4550 .

Saitou, N. \& Nei, M. (1987). The neighbor-joining method: a new method for reconstructing phylogenetic trees. Mol Biol Evol 4, 406425 .

Sasser, M. (1990). Identification of bacteria by gas chromatography of cellular fatty acids. USFCC Newsl 20, 16.

Shirling, E. B. \& Gottlieb, D. (1966). Methods for characterization of Streptomyces species. Int J Syst Bacteriol 16, 313-340.

Staneck, J. L. \& Roberts, G. D. (1974). Simplified approach to identification of aerobic actinomycetes by thin layer chromatography. Appl Microbiol 28, 226-231.

Tamaoka, J., Katayama-Fujimura, Y. \& Kuraishi, H. (1983). Analysis of bacterial menaquinone mixtures by high performance liquid chromatography. J Appl Bacteriol 54, 31-36.

Tamura, T. \& Sakane, T. (2004). Planotetraspora silvatica sp. nov. and emended description of the genus Planotetraspora. Int J Syst Evol Microbiol 54, 2053-2056.

Tamura, T., Suzuki, S. I. \& Hatano, K. (2000). Acrocarpospora gen. nov., a new genus of the order Actinomycetales. Int J Syst Evol Microbiol 50, 1163-1171.

Tamura, K., Dudley, J., Nei, M. \& Kumar, S. (2007). MEGA4: molecular evolutionary genetics analysis (MEGA) software version 4.0. Mol Biol Evol 24, 1596-1599.

Thompson, J. D., Gibson, T. J., Plewniak, F., Jeanmougin, F. \& Higgins, D. G. (1997). The CLUSTAL_X windows interface: flexible strategies for multiple sequence alignment aided by quality analysis tools. Nucleic Acids Res 25, 4876-4882.

Williams, S. T., Goodfellow, M., Alderson, G., Wellington, E. M. H., Sneath, P. H. A. \& Sackin, M. J. (1983). Numerical classification of Streptomyces and related genera. J Gen Microbiol 129, 1743-1813.

Xu, P., Li, W. J., Tang, S. K., Zhang, Y. O., Chen, G. Z., Chen, H. H., Xu, L. H. \& Jiang, C. L. (2005). Naxibacter alkalitolerans gen. nov., sp. nov., a novel member of the family Oxalobacteraceae isolated from China. Int J Syst Evol Microbiol 55, 1149-1153. 